\section{Antidepressiver og klinisk praksis}

Antidepressiver er effektive som behandling av «depresjoner» i allmennpraksis - «number needed to treat» (NNT) er 7 (1). Det er bedre enn mange andre medikamentelle intervensjoner i medisinen. Svenske legemiddelmyndigheter har gjort en grundigere analyse av effektdata for antidepressiver enn undersøkelsen til Kirsch og medarbeidere. De konkluderer med at antidepressiver er mer effektive enn placebo, uavhengig av initial depresjonsalvorlighet (2).

Langtidsstudier viser færre tilbakefall hvis man fortsetter med antidepressive legemidler enn hvis man seponerer. NNT er anslått til 5 i forhold til placebo (3), men gode studier fra allmennpraksis mangler. Til sammenlikning er NNT 16 hva gjelder forebygging av alvorlig hjertesykdom ved bruk av statiner. Det kan være aktuelt med langvarig behandling allerede etter første nye episode hvis det er risiko for nye episoder.

Antidepressiver forskrives hyppigere hvis det foreligger selvmordstanker. Korrigerer man for antall selvmordstanker og forsøk siste måned forut for behandlingskontakt, viser forskning at det ikke er økning knyttet til bruk av antidepressiver sammenliknet med psykoterapi (4). Hos dem under 25 år er det - på gruppenivå en lett økning i forekomst av selvmordstanker, men ikke i gjennomførte suicid. Derimot er det prospektive undersøkelser som viser at antidepressiver faktisk kan redusere forekomsten av selvmord (5).

Min vurdering av kunnskapsfronten er at det er trygt å bruke antidepressiver som monoterapi i behandling av bipolare lidelser av type II og type III. Bipolare depresjoner er som regel kjennetegnet ved melankolsk symptomatologi som responderer særlig godt på antidepressiver (6).

Legers ansvar for eventuell feil bruk av antidepressiver bør ikke skyves over på legemiddelindustriens markedsføring. Legemiddelindustrien redegjør også for bivirkninger og risiko, i motsetning hva tilfellet ofte er hos dem som ensidig kun fremmer andre terapiformer.

Vaaler \& Fasmer og jeg er enige om at dagens praksis ved forskrivning av antidepressive legemidler kan bli mer individualisert (7). Vi kan bli flinkere til å integrere psykososiale og medikamentelle tiltak i behandling av depresjoner. Men å hevde at det foreligger empirisk dokumentasjon for at norske legers forskrivningspraksis radikalt må endres, kan jeg ikke se at Vaaler \& Fasmer har grunnlag for, ut fra de data de legger til grunn i sin kronikk.

Ulrik Fredrik Malt

ulrik.fredrik.malt@ous-hf.no

Ulrik Fredrik Malt (f. 1946) er avdelingsleder ved Oslo universitetssykehus, Rikshospitalet, og professor ved Universitetet i Oslo.

Oppgitte interessekonflikter: Han har mottatt honorar for å forelese om antidepressive legemidler ved kurs arrangert av Norsk psykiatrisk forening og som ledd i masterstudiet ved Farmasøytisk institutt, Universitetet i Oslo. Han har også fått honorar for å forelese om antidepressiver for alle legemiddelfirmaer som produserer antidepressiver samt fra Helsedirektoratet for medvirkning i utarbeiding av nasjonale behandlingsveiledere for depresjoner og bipolare lidelser.

\section{Litteratur}

1. Arroll B, Elley CR, Fishman T et al. Antidepressants versus placebo for depression in primary care. Cochrane Database Syst Rev 2009; 3: CD007954.

2. Melander H, Salmonson T, Abadie E et al. A regulatory Apologia-a review of placebo-controlled studies in regulatory submissions of new-generation antidepressants. Eur Neuropsychopharmacol 2008; 18: 623-7.

3. BestPractice. http://bestpractice.bmj.com/best-practice/monograph/55/ treatment.html; (2.3.2013).

4. Simon GE, Savarino J. Suicide attempts among patients starting depression treatment with medications or psychotherapy. Am J Psychiatry 2007; 164: 1029-34.

5. Angst J, Hengartner MP, Gamma A et al. Mortality of 403 patients with mood disorders 48 to 52 years after their psychiatric hospitalisation. Eur Arch Psychiatry Clin Neurosci 2012. E-publisert 4.11.
6. Yang S-J, Stewart R, Kang H-J et al. Response to antidepressants in major depressive disorder with melancholic features: the CRESCEND study. J Affect Disord 2013; 144: 42-50.

7. Vaaler AE, Fasmer OB. Antidepressive legemidler - klinisk praksis må endres. Tidsskr Nor Legeforen 2013; 133: 428-30.

Dette er en redigert versjon av et innlegg publisert som rask respons på nett 3.3. 2013. http://tidsskriftet.no/article/2975531/

\section{Antidepressiver og depresjon}

Vaaler \& Fasmer refererer i Tidsskriftet nr. 4/2013 to metaanalyser som viser at antidepressiver hovedsakelig har effekt på alvorlig depresjon (1), mens det er liten eller ingen effekt på lett og moderat depresjon. De nevner ikke den tredje metaanalysen, som viste effekt ved alle grader av depresjon (2).

Heller ikke nevner de den første forskningssyntesen av antidepressiver med komplette longitudinelle data på individnivå $(3,4)$. Den inkluderte alle sammenliknbare publiserte og upubliserte seksukers randomiserte, kontrollerte studier av fluoksetin og venlafaksin med minst 30 pasienter. Med fluoksetin var det 12 voksenstudier, fire geriatristudier og tre ungdomsstudier med totalt 4303 pasienter og 21793 depresjonsmålinger, med venlafaksin var det 21 voksenstudier med 2421 pasienter og 10634 målinger. Effekten var bedre enn i metaanalysene og uavhengig av alvorlighetsgrad (3). Forskjellen hos voksne i respons mellom medikament og placebo var i overkant av $20 \%$.

Fra et folkehelseperspektiv karakteriserte forfatterne dette som en enorm forskjell - for hver femte pasient ville ytterligere én pasient behandlet med aktiv medisin respondere. For ungdom var forskjellen enda større - $24 \%$ - pga. lav placeborespons. Hos geriatriske pasienter var forskjellen bare $10 \%$. «Results of this study raise serious questions regarding the results of meta-analyses that are now so prevalent in guiding medical decisions,» skriver forfatterne (3). Metaanalyser er observasjonsstudier av studier, og fordelene ved randomisering går dermed tapt. Også studiene til Gibbons og medarbeidere $(3,4)$ er blitt kritisert $(5,6)$, men kritikken er solid imøtegått (7).

Vaaler \& Fasmer refererer en oversiktsartikkel som viste at risikoen for suicid ved behandling med antidepressiver er 2-3 ganger høyere enn med placebobehandling. Gibbons og medarbeidere (4) fant derimot at fluoksetin og venlafaksin reduserte suicidaltanker og -atferd hos voksne og hos geriatriske pasienter parallelt med reduksjon av depresjon, mens det ikke var noen endring hos ungdom. Når det skjer suicid under behandling, skyldes det neppe antidepressiver, men at litium, elektrokonvulsiv terapi og atypiske antipsykotika ikke også er brukt, eventuelt at man ikke har klart å stoppe et farlig alkoholforbruk. Det er viktigere å evaluere vår egen praksis på disse områdene enn å vektlegge et mulig overforbruk av antidepressiver.

\section{Per Bergsholm}

per.bergsholm@gmail.com

Per Bergsholm (f. 1945) er dr.med. og overlege ved Avdeling for akuttpsykiatri, Oslo universitetssykehus, Ullevål.

Ingen oppgitte interessekonflikter.

\section{Litteratur}

1. Vaaler AE, Fasmer OB. Antidepressive legemidler - klinisk praksis må endres. Tidsskr Nor Legeforen 2013; 133: 428-30.

2. Melander $\mathrm{H}$, Salmonson T, Abadie E et al. A regulatory apologia - a review of placebo-controlled studies in regulatory submissions of new-generation antidepressants. Eur Neuropsychopharmacol 2008; 18: 623-7.

3. Gibbons RD, Hur K, Brown CH et al. Benefits from antidepressants: synthesis of 6-week patient-level outcomes from double-blind placebo-controlled randomized trials of fluoxetine and venlafaxine. Arch Gen Psychiatry 2012; 69: 572-9. 
4. Gibbons RD, Brown $\mathrm{CH}$, Hur K et al. Suicidal thoughts and behavior with antidepressant treatment. Reanalysis of the randomized placebo-controlled studies of fluoxethine and venlafaxine. Arch Gen Psychiatry 2012; 69: $580-7$.

5. Spielmans GI, Jureidini J, Healy D et al. Inappropriate data and measures lead to questionable conclusions. JAMA Psychiatry 2013; 70: 121-2.

6. Carroll BJ. Suicide risk and efficacy of antidepressant drugs. JAMA Psychiatry 2013; 70: $123-4$

7. Gibbons RD, Brown $\mathrm{CH}$, Hur $\mathrm{K}$ et al. Suicide risk and efficacy of antidepressant drugs - reply. JAMA Psychiatry 2013; 70: 122-5.

Dette er en redigert versjon av et innlegg publisert som rask respons på nett 12.3. 2013. http://tidsskriftet.no/article/2975531/

\section{A.E. Vaaler \& O.B. Fasmer svarer:}

Det er gjort en rekke metaanalyser vedrørende forskjeller mellom antidepressive legemidler og placebo. Det er mulig å kritisere metodevalget $i$ alle slike arbeider. Vi viser til to arbeider som anses å være sentrale. Det finnes metaanalyser med mer positive eller mer negative resultater i forhold til placebo enn våre to nevnte. Og det finnes metaanalyser som ikke viser noen fordel for antidepressiver sammenliknet med placebo overhodet (1).

Kronikkformen har plassbegrensninger som gjør at ikke alle aspekter av temaet antidepressive legemidler kan tas med. Effekter av ulike terapiformer ved depresjoner og medikamentelle alternativer til antidepressive legemidler er eksempler på dette. I vår kronikk omtalte vi heller ikke de hyppig forekommende somatiske bivirkninger av antidepressive legemidler, for eksempel seksuelle dysfunksjoner. Det samme gjelder restsymptomer og redusert livskvalitet hos deprimerte pasienter som er vurdert å ha klinisk effekt av antidepressive legemidler. Nye data tyder på at dette er et betydelig klinisk problem - opptil $60 \%$ av pasientene er beskrevet med en slik tilstand (2).

I studier av langtidsbruk av antidepressive legemidler er det rapportert færre tilbakefall hos pasienter som fortsetter med uendret medisinering sammenliknet med dem som bytter ut aktivt medikament med placebo. Denne forskjellen er imidlertid begrenset til de første seks måneder. Deretter er det ingen forskjell. Data tyder på at de rapporterte positive resultater til fordel for langtidsbruk av antidepressiver for en stor del skyldes primær toleranseutvikling og abstinens etter seponering i gruppen av pasienter som bytter til placebo (3). Lengre eksponering for antidepressive legemidler forut for randomisering til placebo gir økt risiko for tilbakefall (4).

Vår kronikk konkluderte med at vi trenger legemiddelinformasjon fra uavhengige kilder. Slik informasjon vil endre forskrivningspraksisen. Vi påpekte at legemiddelindustrien driver ukritisk markedsføring - bivirkninger bagatelliseres og kritiske argumenter blir ikke tatt seriøst. Legemiddelindustriens svar på kronikken mer bekrefter enn avkrefter vår konklusjon.

\section{Arne E. Vaaler}

arne.e.vaaler@ntnu.no

Ole Bernt Fasmer

Arne E. Vaaler (f. 1954) er førsteamanuensis ved Norges teknisk-naturvitenskapelige universitet og overlege ved Seksjon for akuttpsykiatri, St. Olavs hospital.

Ingen oppgitte interessekonflikter.

Ole Bernt Fasmer (f. 1952) er professor dr.med. og leder ved Seksjon for psykiatri, Institutt for klinisk medisin, Universitetet i Bergen, og undervisningsansvarlig i Psykiatrisk divisjon, Helse Bergen.

Ingen oppgitte interessekonflikter.

\section{Litteratur}

1. Barbui C, Furukawa TA, Capriani A. Effectiveness of paroxetine in the treatment of acute major depression in adults: a systematic re-examination of published and unpublished data from randomized trials. CMAJ 2008; 178: 296-305.

2. Price J, Cole V, Goodwin GM. Emotional side-effects of selective serotonin reuptake inhibitors: qualitative study. Br J Psychiatry 2009; 195: $211-7$.

3. El-Mallakh RS, Briscoe B. Studies of long-term use of antidepressants: how should the data from them be interpreted? CNS Drugs 2012; 26: 97-109.

4. Viguera AC, Baldessarini RJ, Friedberg J. Discontinuing antidepressant treatment in major depression. Harv Rev Psychiatry 1998; 5: 293-306.

\section{Den Gud gir et embete}

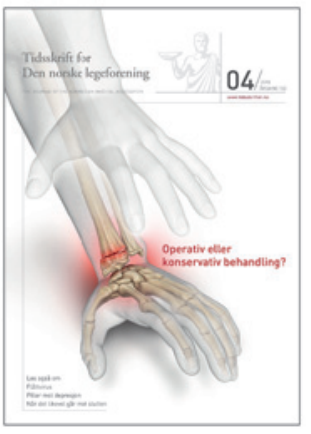

En artikkel i Tidsskriftet nr. 4/2012 omhandlet bl.a. ordspråket «Den Gud gir et embete, gir han også forstand» (1). Om det bare var så enkelt, ville jo det meste bli bra. Det kan imidlertid diskuteres om ordspråket egentlig er slik.

Elisabeth Swensen har hevdet at den opprinnelige ordlyden antakelig er «Den Gud giver et embede»... den give Han også forstand» - det vil si at ordspråket inneholder et imperativ snarere enn en påstand. Swensen mener forskjellen i betydning er «potensielt katastrofal» (2).

Mot den ordinære forståelsen om at det automatisk følger klokskap med makt, setter Swensen bønnen om at den som får en betrodd stilling, også må få forstand. Jeg er enig med henne i at forskjellen er potensielt katastrofal dersom den som får embetet, tror at forstanden automatisk følger med, og/eller hvis den som utnevner, tror det samme.

\section{Kåre Ertresvåg}

karearne@gmail.com

Kåre Ertresvåg (f. 1940) er spesialist i generell kirurgi og overlege ved Diakonhjemmet Sykehus

Ingen oppgitte interessekonflikter.

\section{Litteratur}

1. Lærum OD. Styring av vitenskap på ville veier. Tidsskr Nor Legeforen 2013; 133: 441-4.

2. Swensen E. Den Gud giver et embete... Hovedforelesning på primærmedisinsk uke 2012. http://elswense.wordpress.com/2012/12/08/den-gud-giver-etembede-hovedforelesning-pa-primaermedisinsk-uke-2012/ (19.2.2013).

Dette er en redigert versjon av et innlegg publisert som rask respons på nett 19.2. 2013. http://tidsskriftet.no/article/2976306/ 